\title{
Characterization and nutritional assessment of traditional dairy products from the Zlatibor
} region, Republic of Serbia

\author{
D. Milićević* , G. Krešić, D. Vranić, T. Lešić, J. Nedeljković-Trailović, \\ S. Janković and J. Pleadin
}

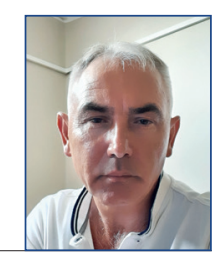

\begin{abstract}
The aim of this study was to determine the nutritional properties of raw milk, cheese and a traditional creamy dairy product called kajmak originating from the Zlatibor region in Serbia. Chemical composition, minerals, fatty acid (FA) profile, lipid quality indices, and the dietary intake of saturated fatty acids (SFA), cholesterol, salt and sodium were investigated in three sampling sessions during the period June-September 2019. All chemical properties of raw milk, cheese and kajmak differed significantly $(P<0.05)$, except lactose, salt and total proteins. Palmitic acid (C16:0) was present in the highest share, followed by oleic (C18:1 cis-9) and myrstic (C14:0) acids, with no significant differences $(P>0.05)$ between
\end{abstract}

products. Among the FAs, conjugated linoleic acids (CLA) were determined, and mean values of total FAs ranged from $0.16 \%$ in raw milk and kajmak to $0.31 \%$ in cheese. The recommended values for the lipid quality indices were not obtained for the analysed products. Despite a high sodium content, the tested dairy products can be considered valuable sources of calcium, chromium, zinc and selenium. In the future, additional efforts should be employed in product modification with the aim of optimising nutritional value and to obtain the protect designation of origin.

Key words: raw milk; cheese and kajmak; nutritional assessment; traditional recipes, Zlatibor region

\section{Introduction}

Due to their nutritional value and the health-related benefits of regular consumption, milk and dairy products are

an integral part of the daily diet during the entire human lifespan (US Department of Health and Human Services, 2020). These

\footnotetext{
Dragan MILIĆEVIĆ*, DVM, PhD, Principal Research Fellow (Corresponding author, e-mail: dragan. milicevic@inmes.rs), Danijela VRANIĆ, PhD, Senior Research Associate, Saša JANKOVIĆ, PhD, Senior Research Associate, Belgrade, Serbia; Greta KREŠIĆ, BSc, PhD, Full Professor, Faculty of Tourism and Hospitality Management, University of Rijeka, Opatija, Croatia; Tina LEŠIĆ, MSc, BSc, Expert Associate, PhD student, Jelka PLEADIN, BSc, PhD, Scientific Advisor in Tenure, Full Professor, Croatian Veterinary Institute, Zagreb, Croatia; Jelena NEDELJKOVIĆ-TRAILOVIĆ, DVM, PhD, Full Professor, Faculty of Veterinary Medicine, University of Belgrade, Belgrade, Serbia
} 
products are rich in necessary building and regulating components, including minerals, fat-soluble vitamins $(\mathrm{A}, \mathrm{D}, \mathrm{E}$, and $\mathrm{K})$, and fat as a source of energy (Vulić et al., 2021). The protein in cow milk is of high-quality, containing a good balance of all the essential amino acids, including lysine (defined asprotein that supports maximal growth). Cow milk accounts for 83 percent of the global overall milk production (FAOSTAT, 2012). Over the past decade, the concept of dairy production has changed dramatically, with increasing orientation towards the production of "value-added products", some of which are segmented into the "health and wellness" market. Studies have also shown that milk from traditional family farms, especially in Mediterranean countries, represent a valuable raw material for the production of different dairy products, such as high quality hard cheese as the most important product (Alichanidis and Polychroniadou, 2008).

The Zlatibor region in Serbia is a hilly and mountainous area with widespread traditional, artisanal processing of dairy products. However, recently, the focus in dairy manufacturing conditions has shifted towards improving the quality and safety of dairy products. Due to its specific geographical position and natural features, the Zlatibor region is one of the most interesting highlands area in Southeast Europe and one of the top two tourism destinations in Serbia. The strong interest of tourists in traditional, local products gives the potential for additional valorisation of Zlatibor dairy products, with the need to increase their visibility, particularly with protection of the label of geographical indices. Furthermore, the quality of milk and dairy products tends to be tailored to meet the demand of the national culture, economy, and public health, and to promote their further development.

To date, there have been no studies conducted to characterise the nutritional composition of milk and dairy products from this area, with a detailed profile of their mineral and FA contents, and this information is also not provided on any labels, which consumers view when making purchasing decisions. Therefore, the aim of this study was to provide characterization and a nutritional assessment of raw milk, cheese and kajmak produced in this region according to traditional recipes, and to determine the relationships with the corresponding milk. Measuring the main chemical parameters of these products also creates a foundation for the development of novel products and to improve the quality of existing products.

\section{Materials and methods}

\section{Production technology}

The dairy cows giving the milk analysed in this study, all of the Simmental breed, were fed silage originating from a defined locality, with a minor extent of concentrated food originating from or outside the defined area of production. The local small dairy has a capacity of 1,500 litres of milk per day and processes milk only from registered agricultural farms (30), situated in the southwestern mountain region of Zlatibor, Serbia $\left(43^{\circ} 31^{\prime}-43^{\circ} 51^{\prime} \mathrm{N}, 19^{\circ} 28^{\prime}-19^{\circ} 56^{\prime} \mathrm{E}\right.$, with a mean elevation of about $1000 \mathrm{~m}$ ).

The technological process of cheese and kajmak production is based on traditional methods, adapted to the conditions of production in dairies. After receiving the milk, it is pasteurized and poured into creamers. After removing the cream, cheese is made from the remaining milk. Milk coagulation is initiated by the action of rennet. From the received $1500 \mathrm{~L}$ of milk, on average, $170 \mathrm{~kg}$ of cheese and about $40 \mathrm{~kg}$ of kajmak are obtained. The finished products are packed in plastic packaging, namely cheese in packages of $1 \mathrm{~kg}$ and $5 \mathrm{~kg}$, and kajmak in packages of $300 \mathrm{~g}, 500 \mathrm{~g}$ and $1000 \mathrm{~g}$. Entities that 
are involved in the production and trade of these products must be entered in the Register of animal breeding holdings and the Central Register of holdings that is kept by the Serbian Ministry of Agriculture.

\section{Sampling procedures and analysis}

For the analysis of raw milk material, a pooled sample of cow's milk was used, collected from individual breeders (small farms), whereas samples of cheese and kajmak were produced by a small, local dairy. In order to assess homogeneity, all samples (raw milk, cheese and kajmak) were taken three times during the period June-September 2019 in the same time intervals, every 40 days, from the same producer and in five replicates, where each sample had a weight of at least 300 g (SFRY Official Gazette 32/83). After sampling, all samples were kept at $4^{\circ} \mathrm{C}$ and analysed within 24 hours of receipt at the laboratory. All chemical analysis were performed in duplicate using accredited or validated analytical methods, with applied quality control (certified reference materials) and regularly annual participation in proficiency test schemes.

\section{Chemical properties}

Methods for determination of the basic chemical ingredients in raw milk (moisture, dry matter, milk fat and total proteins) were carried out completely in accordance with the Ordinance on sampling methods and methods of chemical and physical analysis of milk and milk products (SFRY Official Gazette 32/83). Moisture content in cheese and kajmak was determined by drying of $2-3 \mathrm{~g}$ of sample at $105^{\circ} \mathrm{C}$ until a constant weight was obtained (FIL-IDF, 1987), while dry matter (DM) was calculated as 100$\%$ of moisture. $\mathrm{pH}$ value was measured with a pH meter CYBER SCAN pH 510 (Eutech, Netherlands). Cheese and kajmak fat content were determined using the Gerber method (FIL-IDF, 1981). Fat in dry matter (Fat/DM \%) was calculated by the formula Fat $/ \mathrm{DM} \%=($ cheese fat $\% \mathrm{x}$ 100) / cheese DM \%. For determination of salt content, after acidification, silver nitrate solution was added to the sample, and further titrated with a standard volumetric ammonium thiocyanate solution (AOAC, 1984). To determine total protein, $1 \mathrm{~g}$ of sample was weight and after addition of catalyst (2 tablets) and concentrated sulphuric acid (12 $\mathrm{mL}$ ), its content was determined by the Kjeldahl method (FIL-IDF, 2002), with use of Kjeltec Auto 1030 Analyzer (Foss Tecator AB, Hoganas, Sweden).

Determination of cholesterol was performed according to Maraschiello et al. (1996), using high performance liquid chromatography on an HPLC Waters - 2695 Separation module, with a Photo diode array detector (PDA detector) Waters 2995 (Milford, MA, USA). Chromatographic separation was achieved on a Phenomenex Luna C 18 (2) column $(150 \mathrm{~mm} \times 3.0 \mathrm{~mm}$, particle size $5 \mu \mathrm{m}$ ), with the appropriate precolumn, isocratic, with mobile phase isopropanol-acetonitrile, $20 \%: 80 \%$, v/v, and injected volume of $10 \mu \mathrm{L}$. Cholesterol was determined by absorption at a wavelength of $210 \mathrm{~nm}$.

Sugars were determined by liquid chromatography with detection by measurement of the refractive index (HPLC-RI). The chromatographic system consisted of an isocratic HPLC pump 1515 (Waters, Milford, MA, USA), an autosampler 717 plus (Waters, Milford, MA, USA), detector (2414 Refractive Index Detector) and column temperature control system (Temperature control module). The amino column Luna NH2 150x4.6 mm, Phenomenex, Torrance (CA, USA) was used for the chromatographic separation of sugars. The mobile phase is a mixture of water: acetonitrile $20: 80 \mathrm{v} / \mathrm{v}$, with flow of $2 \mathrm{~mL} / \mathrm{min}$. The temperature of the detector and the column was $30^{\circ} \mathrm{C}$. The injected sample volume was 
$10 \mu \mathrm{L}$ and analysis duration was 10 min. For sample preparation, $20 \mathrm{~g}$ of sample was combined with about $50 \mathrm{~mL}$ boiling water, homogenized for $1 \mathrm{~min}$ at Ultraturrax at about 10,000 rpm, and then cooled. To this, $2 \mathrm{~mL}$ Carrez solution I and II were added, made up to $100 \mathrm{~mL}$ with water and filtered through a nylon filter with a pore size of $0.45 \mu \mathrm{m}$ in the autosampler vial.

\section{Mineral content}

Approximately $0.5 \mathrm{~g}$ of the sample was transferred into a teflon vessel with $5 \mathrm{~mL}$ nitric acid (67\% Trace Metal Grade, Fisher Scientific, Bishop, UK) and 1.5 $\mathrm{mL}$ hydrogen peroxide $(30 \%$ analytical grade, Sigma-Aldrich, St. Louis, MA, USA) for microwave digestion. The microwave (Start D, Milestone, Sorisole, Italy) programme consisted of three steps: $5 \mathrm{~min}$ from room temperature to $180^{\circ} \mathrm{C}, 10 \mathrm{~min}$ hold at $180^{\circ} \mathrm{C}, 20 \mathrm{~min}$ vent. After cooling, the digested sample solutions were quantitatively transferred into disposable flasks and diluted to 100 $\mathrm{mL}$ with deionized water produced by a water purification system (Purelab DV35, ELGA, Buckinghamshire, UK).

Analysis of the following elements: $\mathrm{Fe}, \mathrm{Zn}, \mathrm{Cu}, \mathrm{Mn}$, Se, Cr, Co, Na, K, Mg and $\mathrm{Ca}$, was performed by inductively coupled plasma mass spectrometry (ICPMS), (iCap Q mass spectrometer, Thermo Scientific, Bremen, Germany). The most abundant isotopes were used for quantification. Basic operating conditions of the instrument were: RF power (1550 $\mathrm{W})$; cooling gas flow (14 L/min); nebulizer flow (1 L/min); collision gas flow (1 mL/ min); operating mode (Kinetic Energy Discrimination-KED); dwell time (10 $\mathrm{ms})$. Standard stock solutions containing $1000 \mathrm{mg} / \mathrm{L}$ of each element (Fe, Zn, Cu, $\mathrm{Mn}, \mathrm{Se}, \mathrm{Cr}, \mathrm{Co}, \mathrm{Na}, \mathrm{K}, \mathrm{Mg}, \mathrm{Ca}$ ) were purchased from Reagecon (Shannon, Co. Clare, Ireland). These solutions were used to prepare standards for the fivepoint calibration curves (including zero).
Multielement internal standard $\left({ }^{6} \mathrm{Li},{ }^{45} \mathrm{Sc}\right.$, ${ }^{71} \mathrm{Ga},{ }^{89} \mathrm{Y},{ }^{209} \mathrm{Bi}$ ) was introduced online by an additional line through the peristaltic pump, and covered a wide mass range. All solutions (standards, internal standards and samples) were prepared in $2 \%$ nitric acid.

The quality of the analytical process was verified by analysis of the certified reference materials ERM-CE278k and ERM-BB384 (Institute for Reference Materials and Measurements, Geel, Belgium). Measured concentrations were corrected for response factors of internal standards using the interpolation method and were within the range of the certified values for all isotopes.

\section{Fatty acid profile and triglycerides}

Extraction of total lipids for FA determination wAs performed by accelerated solvent extraction (ASE 200, Dionex, Sunnyvale, CA) with a mixture of petroleum ether and isopropanol (60:40, $\mathrm{v} / \mathrm{v})$. Preparation of fatty acid methyl esters (FAMEs) was done by $0.25 \mathrm{M}$ TMSH (trimethyl sulfonium hydroxide) in methanol (EN ISO 5509:2000) and their determination by capillary gas chromatography with a flame ionization detector on GC Shimadzu 2010 (Kyoto, Japan), equipped with flame ionization detector and capillary HP-88 column (100 m x $0.25 \mathrm{~mm} \times 0.20$ $\mu \mathrm{m}, \mathrm{J} \& W$ Scientific, USA). Separation and detection were performed under the following temperature programme: initial temperature $50^{\circ} \mathrm{C}$, rate $13^{\circ} \mathrm{C} / \mathrm{min}$ to $215^{\circ} \mathrm{C}$, hold $10 \mathrm{~min}$, rate $2^{\circ} \mathrm{C} / \mathrm{min}$ to $230^{\circ} \mathrm{C}$ and hold $10 \mathrm{~min}$. Total analysis time was $63.12 \mathrm{~min}$. The injector and detector temperatures were $250^{\circ} \mathrm{C}$ and $280^{\circ} \mathrm{C}$, respectively; split ratio 1:50; volume $1 \mu \mathrm{L}$, carrier gas, $\mathrm{N}_{2}, 1.87 \mathrm{~mL} / \mathrm{min}$; make-up gas, $\mathrm{N}_{2}, 30 \mathrm{~mL} / \mathrm{min}$; detector gases, $\mathrm{H}_{2}, 40$ $\mathrm{mL} / \mathrm{min}$; and synthetic air, $400 \mathrm{~mL} / \mathrm{min}$.

Triglycerides (TAG) were determined by the same equipment of the liquid chromatographer with detection 
by measurement of refractive index (HPLC-RI), as described earlier for the determination of sugars. Two reversephase columns Luna C18 150x4.6 mm were connected in series, Phenomenex, Torrance (CA, USA) and used for chromatographic separation of TAG. The mobile phase was a mixture of acetone: acetonitrile $64: 36 \mathrm{v} / \mathrm{v}$. The flow of the mobile phase was $1 \mathrm{~mL} / \mathrm{min}$, the internal temperature of the detector $30^{\circ} \mathrm{C}$, and column temperature $25^{\circ} \mathrm{C}$. The injected sample volume was $10 \mu \mathrm{L}$ and the duration of the analysis $40 \mathrm{~min}$. The extraction part of the sample preparation was the same as for determination of FAs. A portion of the extracted fat was dissolved in acetone and filtered in an autosampler vial through a $0.22 \mu \mathrm{m}$ nylon filter. The composition of TAG was determined based on their grouping by equivalent carbon number (ECN). During chromatography, the TAG elutes in the order of their ECN, i.e., the TAG with the lowest ECN have the shortest retention times (RT).

\section{Lipid quality indices}

Data on FA composition were used for the calculation of lipid quality indices, including the atherogenic index (AI), thrombogenic index (TI) and hypocholesterolaemic/ hypercholesterolaemic ratio $(\mathrm{H} / \mathrm{H})$. These parameters were calculated as follows: $\mathrm{AI}=[(\mathrm{C} 12: 0+(4 \times \mathrm{C} 14: 0)+\mathrm{C} 16: 0)] /[\Sigma$ MUFA + PUFA n-6+ PUFA n-3]; TI = $(\mathrm{C} 14: 0+\mathrm{C} 16: 0+\mathrm{C} 18: 0) /\left[0.5 \times \sum\right.$ MUFA + $0.5 \times$ PUFA $n-6+3 \times$ PUFA n-3) + (PUFA n-3/PUFA n-6)], and $\mathrm{HH}=(\mathrm{C} 18: 1 \mathrm{n}-9+$ C18:2n-6 + C20:4n-6 + C18:3n-3 + C20:5n-3 + C22:5n-3 + C22:6n-3) / (C14:0 + C16:0) (Ulbricht and Southgate, 1991).

\section{Estimation of dietary intake}

Dietary intake of saturated fatty acids, cholesterol, salt and minerals were estimated by calculation on the basis of consumption of $100 \mathrm{~g}$ of cheese and kajmak and on the basis of the average per capita consumption data as published in the Household Budget Survey (Statistical Office of Republic of Serbia, 2020). The obtained values were compared with the recommendations (EC, 2011; Institute of Medicine, 2011; WHO, 2012).

\section{Statistical analysis}

All data analysis was performed using the SPSS Statistics Software package 22.0 (SPSS Statistics, IBM NY, USA, 2013). The obtained results were expressed as the mean \pm standard deviation $(\bar{X}+S D)$, minimum ( $\min )$ and maximum $(\max )$ values. To determine the statistical significance of the differences in chemical parameters and FAs composition between milk and dairy products, the one-way ANOVA test was performed. Pearson's bivariate correlation analysis was performed to determine the relationship between chemical components of milk, cheese and kajmak. Decisions on statistical relevance were made at the significance level of $P \leq 0.05$.

\section{Results and Discussion \\ Chemical composition and mineral content}

The basic chemical properties of raw milk, and the mineral content in cheese and kajmak originating from the Zlatibor area are shown in Tables 1, 2 and 3, respectively. The mean value of DM content of cow milk (without fat) was about $8.60 \%$, while fat was about $4.03 \%$ and protein about $3.11 \%$ (Table 1 ). In the current study, the estimated mean value of the main chemical composition of raw cow milk is in accordance with the values listed in the FAO database (FAO, 2013). Therefore, raw milk produced in the Zlatibor region is whole milk and a highquality raw material for dairy production. Milk yield and chemical composition depends on various factors, including animal breed, diet, stage of lactation, 
health status and environmental factors (FAO, 2013; Vulić et al., 2021). Several studies have examined methods to improve nutrient value and sensory quality by changing the animal's diet. Also, most modern dairies begin their manufacturing process by standardizing raw milk to a specified solids content, pasteurizing it and then using for the production of dairy products.

The results of the chemical analysis of cheese and kajmak are summarized in Table 2. Based on the milk fat content in DM (38.44\%) and moisture content $(57.72 \%)$, the cheese analysed in this study was classified as a semi-fat soft cheese, while kajmak is intended to be consumed immediately after production, as fresh kajmak. Results of the chemical properties of cheese and kajmak obtained in this study (Table 2) are comparable with other studies (Pudja et al., 2008; Kučević et al., 2016; Miloradovic et al., 2018). The greatest variability was observed for DM (38.51-44.80\%), milk fat (14.75-17.25\%) and cholesterol (38.99-65.92\%) content in cheese, while the chemical properties of kajmak was similar across the sampling period. Variations in cheese composition observed here could be explained mainly due to technological processes involved in cheese manufacturing. The nutritional profile of cheese varies with the type of milk, the type of starter culture, the method of manufacture and ripening conditions (Lešić et al., 2016). In general, the highest quantity of salt $(3.51 \%)$ was found in cheese, and was up to twice as high as in kajmak. This may be because the cheese was salted with $\mathrm{NaCl}$, to maintain a salty taste ad to ensure microbial stability by maintaining water activity $\left(\mathrm{a}_{\mathrm{w}}\right)$ of the soft cheese. However, a high amount of salt causes the loss of minerals due to osmosis. Also, reducing the sodium content of cheese could have significant health benefits, since dairy products have been listed as the fourth largest source of dietary sodium (Grummer et al., 2012). The $\mathrm{pH}$ value near 5 as obtained here is key point of an optimum cheese-making process, since acidity contributes to the sensory properties of cheese, prevents bacterial growth and consequently enzyme activity and also has an effect on the distribution of minerals. The lactose content showed significant variation during the study period, with levels of 2.06 and $2.86 \%$ in cheese and kajmak, respectively. The average lactose content is in accordance to the type of fresh cheese and kajmak $(1.81 \%$ and $2.11 \%$, respectively), due to relatively short ripening period. Nevertheless, a high level of lactose in dairy products is not suitable for lactose intolerant individuals. Hence, the importance of the starter culture in cheesemaking should be pointed out, as it is necessary for sugar fermentation by lactic bacteria within in the first 10-12 h. Significant differences $(P<0.05)$ were determined between these three product types for all chemical properties (Tables 1 and 2), except the content of lactose and

Table 1. Basic chemical properties of raw milk from Zlatibor region

\begin{tabular}{|l|c|c|}
\hline Parameter $(\%)$ & $\overline{\mathbf{X}} \pm$ SD & Min-Max \\
\hline Moisture & $87.37 \pm 0.07$ & $87.03-87.58$ \\
\hline Dry matter (DM), without fat & $8.60 \pm 0.07$ & $8.39-8.94$ \\
\hline Milk fat & $4.03 \pm 0.34$ & $3.65-4.30$ \\
\hline Total proteins & $3.11 \pm 0.06$ & $3.06-3.18$ \\
\hline
\end{tabular}

DM $(\%)=100$ - water (\%); DM (\%, fat-free) = DM-milk fat; $\bar{X}$-mean value; SD-standard deviation

Results are expressed as the mean value \pm SD of five samples taken in three sampling sessions; each sample was analysed in duplicate 
Table 2. Chemical properties of Zlatibor cheese and Zlatibor kajmak

\begin{tabular}{|c|c|c|c|c|c|}
\hline \multirow{2}{*}{\multicolumn{2}{|c|}{ Parameter }} & \multicolumn{2}{|c|}{ Cheese } & \multicolumn{2}{|c|}{ Kajmak } \\
\hline & & $\overline{\mathrm{X}} \pm \mathrm{SD}$ & Min-Max & $\overline{\mathrm{X}} \pm \mathrm{SD}$ & Min-Max \\
\hline \multicolumn{2}{|c|}{ Moisture (\%) } & $57.72 \pm 3.32 *$ & $55.20-61.49$ & $35.16 \pm 1.46^{*}$ & $33.60-36.50$ \\
\hline \multicolumn{2}{|c|}{ Dry matter (DM) (\%) } & $42.28 \pm 3.32 *$ & $38.51-44.80$ & $64.84 \pm 1.46^{*}$ & $63.50-66.40$ \\
\hline \multicolumn{2}{|c|}{ Milk fat (\%) } & $16.25 \pm 1.32 *$ & $14.75-17.25$ & $57.66 \pm 0.75^{*}$ & $57.07-58.50$ \\
\hline \multicolumn{2}{|c|}{ Milk fat in DM (\%) } & $38.44 \pm 1.13^{*}$ & $37.39-39.64$ & $87.58 \pm 1.48 *$ & $85.95-88.83$ \\
\hline \multicolumn{2}{|c|}{ Total proteins (\%) } & $20.28 \pm 1.42 *$ & $18.66-21.30$ & $4.50 \pm 1.01 *$ & $3.86-5.67$ \\
\hline \multicolumn{2}{|c|}{$\mathrm{pH}$} & $5.15 \pm 0.14^{*}$ & $5.01-5.28$ & $6.06 \pm 0.45^{*}$ & $5.54-6.34$ \\
\hline \multicolumn{2}{|c|}{ Lactose $(\%)$} & $1.81 \pm 0.22$ & $1.62-2.06$ & $2.11 \pm 0.86$ & $1.18-2.86$ \\
\hline \multicolumn{2}{|c|}{ Cholesterol (mg/100 g) } & $48.97 \pm 14.76^{*}$ & $38.99-65.92$ & $179.31 \pm 38.55^{*}$ & $143.6-220.2$ \\
\hline \multicolumn{2}{|c|}{ Salt $(\%)$} & $3.51 \pm 0.20$ & $3.60-3.88$ & $1.88 \pm 1.02$ & $1.12-3.04$ \\
\hline \multirow{2}{*}{ Energy } & (kJ/100 g) & $976.70 \pm 73.19 *$ & 892.89-1028 & $2245.46 \pm 47.2^{*}$ & $2211.72-2299.41$ \\
\hline & (kcal/100 g) & $234.62 \pm 17.63^{*}$ & $214.43-247.0$ & $545.39 \pm 11.36 *$ & $537.29-558.38$ \\
\hline
\end{tabular}

* Statistically significant difference within columns $(P<0.05)$

Results are expressed as the mean value \pm SD of five samples taken in three sampling sessions; each sample was analysed in duplicate

salt, and of total protein content between raw milk and kajmak. Milk fat in raw milk and cheese were strongly positively correlated $(\mathrm{r}=0.999, P=0.05)$, while for no significant correlation was observed between raw milk and milk products for other parameters.

The mean mineral content $(\mathrm{Na}, \mathrm{Ca}, \mathrm{K}$, $\mathrm{Mg}, \mathrm{Zn}, \mathrm{Fe}, \mathrm{Cu}, \mathrm{Mn}$, Se and $\mathrm{Cr}$ ) in cheese and kajmak is shown in Table 3. Cheese contains significant amounts of calcium, zinc, selenium and chromium (4722 mg/ $\mathrm{kg}, 27.1 \mathrm{mg} / \mathrm{kg}, 0.14 \mathrm{mg} / \mathrm{kg}$ and $0.09 \mathrm{mg} /$ $\mathrm{kg}$, respectively). Zlatibor cheese and kajmak did not differ significantly in their mineral compositions, except zinc which was significantly ( $p=0.026$ ) higher in cheese. All minerals considered to be essential to the human diet are present in milk, so milk and dairy products are considered a good source of minerals, except iron. Milk is not a source of iron, and the high calcium and casein contents in milk inhibits the absorption of dietary non-heme iron (FAO, 2013). It is known that the mineral content in raw cow milk varies according to different factors, such as lactation period, health status, dietary composition of animal feed, and environmental and genetic factors (Vahčić et al., 2010). Also, the technology of production has a significant effect on content and ratio of mineral compounds in dairy products (Khattab et al., 2019). Mineral composition in milk products is also related to differences in acidification, heating and salting levels. As a result of milk fermentation, the decrease in milk $\mathrm{pH}$ renders progressively soluble colloidal calcium phosphate, calcium bound to phosphoserines and carboxyls, as well as magnesium bound to casein (Gaucheron, 2011). The rate of acid production and the $\mathrm{pH}$ of whey at draining during cheesemaking are also critical factors that determine the mineral content of cheese (RaynalLjutovac et al., 2008). This could partly explain the wide variability of the mineral contents observed in this study, especially for $\mathrm{Na}, \mathrm{Ca}, \mathrm{K}$ and $\mathrm{Mg}$. 
Table 3. Mineral content of Zlatibor cheese and Zlatibor kajmak

\begin{tabular}{|l|c|c|c|c|}
\hline \multirow{2}{*}{ Minerals (mg/kg) } & \multicolumn{2}{|c|}{ Cheese } & \multicolumn{2}{c|}{ Kajmak } \\
\cline { 2 - 5 } & $\overline{\mathrm{X}} \pm$ SD & Min-max & $\overline{\mathbf{X}} \pm$ SD & Min-max \\
\hline Sodium (Na) & $14916 \pm 543$ & $14429-15501$ & $8758 \pm 5803$ & $4492-15366$ \\
\hline Calcium (Ca) & $4722 \pm 2064$ & $2355-6148$ & $1610 \pm 322$ & $1299-1941$ \\
\hline Potassium (K) & $1301 \pm 297$ & $1079-1638$ & $898 \pm 188$ & $700-1072$ \\
\hline Magnesium (Mg) & $220 \pm 87.4$ & $126-299$ & $111 \pm 29.8$ & $77.0-132$ \\
\hline Zinc (Zn) & $27.1 \pm 9.66 *$ & $16.31-34.92$ & $7.24 \pm 2.27 *$ & $4.65-8.9$ \\
\hline Iron (Fe) & $3.05 \pm 0.49$ & $2.57-3.55$ & $2.13 \pm 0.62$ & $1.68-2.84$ \\
\hline Copper (Cu) & $0.34 \pm 0.05$ & $0.29-0.37$ & $0.19 \pm 0.13$ & $0.05-0.28$ \\
\hline Manganese (Mn) & $0.17 \pm 0.12$ & $0.05-0.25$ & $0.13 \pm 0.07$ & $0.05-0.20$ \\
\hline Selenium (Se) & $0.14 \pm 0.05$ & $0.08-0.20$ & $0.02 \pm 0.01$ & $0.01-0.03$ \\
\hline Chromium (Cr) & $0.09 \pm 0.07$ & $0.02-0.15$ & $0.07 \pm 0.04$ & $0.03-0.11$ \\
\hline
\end{tabular}

* Statistically significant difference within columns $(P<0.05)$

Results are expressed as the mean value \pm SD of five samples taken in three sampling sessions; each sample was analysed in duplicate

Contamination of dairy products with contaminants or residues are a still notable concern, since their presence has been related to environmental pollution (air, water, soil), substances used in animal husbandry practices, animal feedstuff production processes, and sanitary conditions. In the current study (data not presented), the concentrations of toxic elements (arsenic, mercury, lead, cadmium, nickel, cobalt) were far below the permissible limit. Thus, dairy products originating from Zlatibor represent a low risk to human health, in relation to dietary intake of toxic elements.

Generally, the highest content of macroelements sodium and calcium in cheese and kajmak can be explained due to the addition of their salts during production, while the presence of microelements can be linked to the high content of biogenic microelements (Fe, $\mathrm{Co}, \mathrm{Mn}, \mathrm{Se}$ ) in the soil and consequently increased concentrations in grasses used in animal nutrition. Due to a lack of similar research in Zlatibor, we are not able to compare the results obtained here. However, the composition and quantitative sequence of the analysed minerals in this study can be compared with earlier published data for other regional types of cheeses (Zlatar, Homolje, Sjenica) (Barać et al., 2018). The data obtained in this study suggest differences in the chemical composition and mineral content of dairy products from Zlatibor, compared to previous research in other regions.

\section{Fatty acids, triglycerides and lipid quality indices}

One of the main factors affecting cheese quality is the FA profile. The results of the FA profiles of raw milk, cheese and kajmak produced in the Zlatibor area are shown in Table 4 . The results of the FA profiles in this study are in agreement with previous reports that confirm that more than 60 percent of the FAs in all three products are SFAs, among which the content of palmitic $(\mathrm{C} 16: 0)$ acid is highest (27.43-30.93\%), followed by oleic (C18:1cis-9) (24.90-29.78\%) and myristic (C14:0) (9.86-12.42\%) acid content (Yao et al., 2016). However, among the FAs, 
Table 4. Fatty acids profile of raw milk, cheese and kajmak produced in the Zlatibor region

\begin{tabular}{|l|c|c|c|c|c|c|}
\hline \multirow{2}{*}{ Fatty acid (\%) } & \multicolumn{2}{|c|}{ Raw milk } & \multicolumn{2}{c|}{ Cheese } & \multicolumn{2}{c|}{ Kajmak } \\
\cline { 2 - 7 } & $\overline{\mathrm{X}} \pm$ SD & Min-max & $\overline{\mathrm{X}} \pm$ SD & Min-max & $\overline{\mathrm{X}} \pm$ SD & Min-max \\
\hline C4:0 & $4.13 \pm 0.09^{*}$ & $4.04-4.23$ & $4.35 \pm 0.10$ & $4.29-4.46$ & $4.68 \pm 0.33^{*}$ & $4.35-5.00$ \\
\hline C6:0 & $2.05 \pm 0.19$ & $1.93-2.27$ & $2.26 \pm 0.10$ & $2.17-2.36$ & $2.30 \pm 0.23$ & $2.05-2.49$ \\
\hline C8:0 & $1.06 \pm 0.13$ & $0.98-1.21$ & $1.17 \pm 0.10$ & $1.10-1.28$ & $1.15 \pm 0.17$ & $0.99-1.32$ \\
\hline C10:0 & $2.21 \pm 0.39$ & $1.96-2.66$ & $2.38 \pm 0.32$ & $2.11-2.74$ & $2.34 \pm 0.42$ & $2.0-2.81$ \\
\hline C12:0 & $2.38 \pm 0.42$ & $2.08-2.87$ & $2.59 \pm 0.33$ & $2.29-2.94$ & $2.47 \pm 0.43$ & $2.18-2.96$ \\
\hline C14:0 & $10.89 \pm 0.87$ & $9.97-11.7$ & $11.37 \pm 1.24$ & $10.0-12.42$ & $10.82 \pm 1.13$ & $9.86-12.06$ \\
\hline C15:0 & $1.04 \pm 0.05$ & $0.98-1.08$ & $1.09 \pm 0.05$ & $1.04-1.13$ & $1.02 \pm 0.05$ & $0.98-1.07$ \\
\hline C16:0 & $29.65 \pm 1.87$ & $27.50-30.93$ & $29.75 \pm 1.27$ & $28.29-30.59$ & $28.7 \pm 1.17$ & $27.43-29.73$ \\
\hline C17:0 & $0.60 \pm 0.03$ & $0.57-0.63$ & $0.62 \pm 0.05$ & $0.57-0.67$ & $0.60 \pm 0.04$ & $0.56-0.63$ \\
\hline C18:0 & $12.8 \pm 0.75$ & $12.03-13.54$ & $11.51 \pm 0.63$ & $10.97-12.20$ & $12.23 \pm 0.95$ & $11.54-13.31$ \\
\hline C16:1 & $0.93 \pm 0.04$ & $0.89-0.97$ & $1.0 \pm 0.12$ & $0.90-1.13$ & $0.98 \pm 0.07$ & $0.91-1.05$ \\
\hline C18:1trans-11 & $2.84 \pm 0.17$ & $2.65-2.94$ & $2.89 \pm 0.15$ & $2.74-3.03$ & $2.70 \pm 0.28$ & $2.49-3.02$ \\
\hline C18:1cis-9 & $27.0 \pm 2.50$ & $24.96-29.78$ & $26.54 \pm 1.87$ & $24.90-28.58$ & $27.5 \pm 2.32$ & $25.01-29.62$ \\
\hline C18:2n-6 & $1.76 \pm 0.12$ & $1.64-1.89$ & $1.77 \pm 0.29$ & $1.53-2.09$ & $1.85 \pm 0.21$ & $1.67-2.08$ \\
\hline C20:0+C18:3 & $0.27 \pm 0.03$ & $0.25-0.31$ & $0.27 \pm 0.00$ & $0.27-0.27$ & $0.36 \pm 0.11$ & $0.30-0.49$ \\
\hline c9t11CLA & $0.16 \pm 0.01$ & $0.14-0.17$ & $0.31 \pm 0.26$ & $0.15-0.61$ & $0.16 \pm 0.01$ & $0.15-0.17$ \\
\hline C20:4n-6 & $0.19 \pm 0.08$ & $0.11-0.28$ & $0.14 \pm 0.01$ & $0.13-0.14$ & $0.12 \pm 0.01$ & $0.12-0.14$ \\
\hline SFA & $66.82 \pm 2.84$ & $63.64-69.13$ & $67.08 \pm 2.49$ & $64.32-69.15$ & $66.31 \pm 2.57$ & $64.46-69.24$ \\
\hline MUFA & $30.77 \pm 2.64$ & $28.54-33.69$ & $30.43 \pm 2.03$ & $28.60-32.62$ & $31.20 \pm 2.34$ & $28.61-33.16$ \\
\hline PUFA & $2.38 \pm 0.19$ & $2.22-2.60$ & $2.26 \pm 0.44$ & $1.83-2.70$ & $2.46 \pm 0.25$ & $2.24-2.73$ \\
\hline
\end{tabular}

* Statistically significant difference within columns $(P<0.05)$

SFA - saturated fatty acids; MUFA - monounsaturated fatty acids; PUFA - polyunsaturated fatty acids

Results are expressed as mean value \pm SD of five samples taken in three sampling sessions; each sample was analysed in duplicate

conjugated linoleic acids (CLA) were also determined, with mean values of total FAs in the range from $0.16 \%$ in raw milk and kajmak to $0.31 \%$ in cheese. The high values of CLA in milk may be linked to grazing feeding effects. Among FAs, CLA is widely studied in ruminants due its anticancerogenic effects in experimental animals (Govari et al., 2020). The level of CLA was shown to be higher in cow and sheep milk than in other milks (Pietrzak-
Fiećko and Kamelska-Sadowska, 2020). Studies also pointed out that dairy products are the main source of CLA in the human diet and that dairy products contain on average $0.4-1.7 \%$ CLA of total FAs (Ferlay and Chilliard, 2020). In this study, no significant differences were found between raw milk, cheese and kajmak in the proportion of FAs, except for C4:0 between kajmak and milk, indicating that the FA profiles of these products 
were directly related to the parent milk.

Milk fatty acids are derived almost equally from two sources: feed and de novo synthetised as a result of microbial activity in the rumen of the cow. De novo synthetised FAs $(\sim 40 \%)$ include short chain (C4:0-C12:0) and medium chain (C14:0 and partly C16:0), while other saturated fatty acids and long chain unsaturated FAs originate from feed. Therefore, the FA composition of milk may be influenced by several factors, such as diet, stage of lactation, health, and animal breed (Woods and Fearon, 2009), resulting in high variability of their FA profiles. Of all the factors that affect the amount and composition of milk fat, nutrition is the most important. Feeding systems based on herbage (Hurtaud et al., 2014), especially highland pasture (Bergamaschi et al., 2016), have been shown to yield milk and dairy products with FA profiles more beneficial to human health. Therefore, a balanced diet is a basic prerequisite for good production. However, studies have also shown that milk contains significant amounts of lauric acid (C12:0), myristic acid (C14:0), and palmitic acid (C16:0), which have been linked to negative effects on human health, especially because of increased risk of cardiovascular disease. So many studies recommend a decrease in C16:0 as this FA is present in milk fat in high concentrations (Huth and Park, 2012; FAO, 2013).

The results of triglycerides (TAG), TFA and lipid quality indices obtained in raw milk, cheese and kajmak samples in this study are shown in Table 4 . The TAG structure of milk is responsible for the rheological properties of milk fat and its behaviour during melting and crystallization. Their composition is of interest, because it can be used to verify the origin of milk fat (Park et al., 2007). In this study, TAG composition did not differ significantly between milk and milk products and has the highest content of $\mathrm{CN} 42-50$ and lowest of $\mathrm{CN}$ 32-34. A similar distribution of TAG CN proportion was reported by Precht (1992) for cow milk with $8.9 \%$ for CN 32-34, $33.2 \%$ for CN $36-40$ and $41.1 \%$ for CN $42-$ 50 , respectively. Dairy products typically contain 3-6\% trans fatty acids (TFAs) per gram of fat (EFSA, 2010). However, these values depend on the diet of the animals, and neither thermal nor mechanical treatments applied during processing had any effect on the trans-FA content. Elaidic acid (trans-9 C18:1) is one of the major TFAs, although during hydrogenation of polyunsaturated fatty acids (PUFAs), small amounts of other TFAs are produced, including: trans-9,cis-12 C18:2; cis-9,trans-12 C18:2; cis-9, cis-12,trans-15 C18:3; and cis-5,cis-8, cis-11, cis14,trans-17 C20:5 (Filip et al., 2010). TFAs have an adverse impact on cholesterol metabolism as they raise LDL-cholesterol and reduce HDL-cholesterol level, and increase the ratio of total cholesterol to HDL-cholesterol and triglyceride levels in the body (EFSA, 2010). These FAs are usually associated with an increased risk for the development of cardiovascular disease. Since health organizations have recommended reducing TFA intake to the lowest possible level, the presence of industrial TFAs in final products not higher than 2/100 $\mathrm{g}$ of fat (EFSA, 2010). However, while industrially produced TFAs are well known for their negative effects on human health, some researchers have proposed that ruminant TFAs have dissimilar effects on cardiovascular disease risk factors (Vučić et al., 2015). In this study, the determined TFA were vaccenic acid (trans-11 C18:1) and already described CLA. Trans-vaccenic acid makes up about $30-50 \%$ of total TFAs in milk fat (FAO, 2013). The share of analysed TFA was around 3\% of total FAs with no significant difference among milk and dairy products. When considering the share of total TFAs per gram of fat, values of $0.11 \%, 0.49 \%$ and $1.56 \%$ for milk, 
cheese and kajmak, respectively, are not higher than the recommended $2 \%$. Milk and dairy products represent a significant contribution of cholesterol intake, since these products are consumed daily. The cholesterol content in cheese is mainly related to cow milk composition. The average content of cholesterol in cheese and kajmak (48.97 and $179.31 \mathrm{mg} / 100 \mathrm{~g}$, respectively), are in accordance with those found in the literature for several low-fat cheese varieties.

Modern diets are characterized by an excessive intake of fat, especially SFAs and by the disbalance of increased $n-6$ PUFA to n-3 PUFA intake. The PUFA/SFA ratio is the most common parameter used to evaluate the nutritional quality of fat and potential effects on consumer health (Trbovic et al., 2017). In order to meet the health recommendations or reduce the risk of developing cardiovascular and other chronic diseases, the PUFA/ SFA ratio should be greater than 0.4 (EFSA, 2010). To assess the impact on human health, the literature also suggests determination of indices that take the functional properties of FAs into account, such as $\mathrm{AI}, \mathrm{TI}$ and $\mathrm{H} / \mathrm{H}$. AI refers to the relationship between the sum of the main saturates and the main non-saturates FAs, the former being considered pro-atherogenic and the latter being considered anti-atherogenic (Ulbricth and Southgate, 1991), while TI represents the relationship between pro-thrombogenic (saturated) and anti-thrombogenic (unsaturated) FAs, showing a tendency towards blood vessel clotting. $\mathrm{H} / \mathrm{H}$ is the ratio between FAs which are hypocholesterolemic and hypercholesterolemic, and take into account the known effects of certain FAs on cholesterol metabolism (Lecerf, 2009). The recommended values of PUFA/SFA (higher than 0.4) as also of AI, TI (lower than 1) and $\mathrm{H} / \mathrm{H}$ (as higher as possible) were not obtained in this study in any type of the product. However, in some studies (Paszczyk et al., 2019), cow milk had the highest values of AI (3.31 \pm 0.21$)$ and TI $(3.59 \pm 0.19)$, higher than obtained in this study.

In comparison to similar studies carried out in Serbia, the results presented here showed that there are differences although small, attributable to nutritive characteristics of dairy products originating from Zlatibor. The observed variations in the nutritional content could be attributed to numerous factors including milk composition, seasonal variations, and local conditions and practices (Barać et al., 2018).

\section{Estimation of dietary intake}

Recent recommendations for healthy eating advise a daily dietary intake of milk and dairy products of 2 servings for children 2-3 years old; 2.5 servings for children 4-8 years old and 3 servings for children older than 9 years and adults, including pregnant and lactating women. One serving is equivalent to 1 cup of milk or yoghurt and 42-56 g of cheese (US Department of Health and Human Services, 2020). Meeting recommendations for dairy intake should reduce the risk of type 2 diabetes and is associated with lower blood pressure and a reduced risk of cardiovascular disease (Rice et al., 2013). Cheese and kajmak are among the traditional Serbian specialties that represent a significant part of the diet of the Serbian population. It is estimated that more than $30 \%$ of the daily intake of all nutrients comes from traditionally prepared meals.

Since they give a high contribution to the intake of total fats (up to $49 \%$ ), it is evident that they can be associated with nutritional risk factors for the development of cardiovascular disease, which are the most common causes of morbidity and mortality in Serbia (IPHS, 2018). Due to the high share of saturated FAs, the dietary intake of $100 \mathrm{~g}$ of cheese or kajmak should contribute to the more 
Table 5. Triglycerides (TAG), total trans-fatty acids (TFA) and lipid quality indices determined in analysed raw milk, cheese and kajmak produced in the Zlatibor area

\begin{tabular}{|l|c|c|c|c|c|c|c|}
\multirow{2}{*}{ Parameter } & \multicolumn{2}{|c|}{ Raw milk } & \multicolumn{2}{c|}{ Cheese } & \multicolumn{2}{c|}{ Kajmak } & \\
\cline { 2 - 9 } & $\overline{\mathrm{X}} \pm$ SD & Min-max & $\overline{\mathrm{X}} \pm$ SD & Min-max & $\overline{\mathrm{X}} \pm$ SD & Min-max & $P$ value \\
\hline TAG CN 32-34 & $14.43 \pm 2.39$ & $12.07-16.85$ & $14.76 \pm 0.82$ & $14.16-15.69$ & $12.77 \pm 2.57$ & $9.89-14.85$ & 0.496 \\
\hline TAG CN 36-40 & $35.48 \pm 1.73$ & $33.54-36.88$ & $36.33 \pm 2.30$ & $34.83-38.97$ & $36.65 \pm 2.09$ & $34.96-38.99$ & 0.782 \\
\hline TAG CN 42-50 & $50.08 \pm 1.62$ & $48.74-51.89$ & $48.92 \pm 3.10$ & $45.34-50.75$ & $49.30 \pm 2.8$ & $46.16-51.47$ & 0.858 \\
\hline Total TFA & $3.00 \pm 0.18$ & $2.79-3.10$ & $3.20 \pm 0.32$ & $2.89-3.20$ & $2.86 \pm 0.28$ & $2.66-3.18$ & 0.350 \\
\hline Al & $1.30 \pm 0.19$ & $1.09-1.46$ & $1.35 \pm 0.17$ & $1.15-1.48$ & $1.26 \pm 0.17$ & $1.14-1.45$ & 0.830 \\
\hline TI & $3.09 \pm 0.34$ & $2.70-3.35$ & $3.18 \pm 0.28$ & $2.86-3.36$ & $2.91 \pm 0.31$ & $2.70-3.27$ & 0.584 \\
\hline H/H & $0.732 \pm 0.11$ & $0.64-0.85$ & $0.69 \pm 0.09$ & $0.63-0.80$ & $0.76 \pm 0.1$ & $0.65-0.82$ & 0.806 \\
\hline PUFA/SFA & $0.04 \pm 0.00$ & $0.03-0.04$ & $0.03 \pm 0.01$ & $0.03-0.04$ & $0.04 \pm 0.00$ & $0.03-0.04$ & 0.729 \\
\hline MUFA/SFA & $0.46 \pm 0.06$ & $0.41-0.53$ & $0.45 \pm 0.05$ & $0.41-0.51$ & $0.47 \pm 0.05$ & $0.41-0.51$ & 0.935 \\
\hline
\end{tabular}

* Statistically significant difference within columns $(P<0.05)$

TFA - trans-fatty acids; SFA - saturated fatty acids; PUFA - polyunsaturated fatty acids; AI - atherogenic index; TI thrombogenic index; $\mathrm{H} / \mathrm{H}$ - ratio of hypocholesterolaemic to hypercholesterolaemic fatty acids

Results are expressed as mean value \pm SD of five samples taken in three sampling sessions; each sample on TAG was analysed in duplicate

than half or even double, respectively, of the recommended intake of $20 \mathrm{~g}$ per day of saturated FAs. Similarly, the intake of cholesterol from the tested products was in a range of 16.23 to $59.77 \%$ of the recommendations (Table 5).

Regarding mineral content, milk and dairy products are important sources of calcium, magnesium, selenium and zinc (Gaucheron, 2011). Selenium and zinc are especially valuable due to their welldocumented antioxidative effects (Khan et al., 2019). To determine the nutritional value of cheese or kajmak, fulfilments of the daily needs of various populations were estimated by comparison with the recommendations expressed as dietary reference intakes (DRI) (Institute of Medicine, 2011). In the present study, the fulfilment of recommendation was recorded in descending order as follows: sodium $>$ calcium $>$ chromium $>$ zinc $>$ sele nium. The obtained data revealed that the sodium content in $100 \mathrm{~g}$ cheese either fulfil or exceeded the daily needs of all populations. For most population groups, fulfilment of daily needs through cheese was $99.4 \%$ DRI and excess of recommendations was in the range of $114.74-149.16 \%$ DRI. The significantly higher fulfilments were obtained for children $(P<0.05)$ and males and females older than 50 years $(P<0.05)$ in comparison with other population groups. Salt intake with cheese and kajmak was in the range of $42.8-70.13 \%$. This should be of concern since sodium (in the form of salt) is widespread in food and due to the negative health effects of high salt intake (i.e., increased blood pressure, heart and kidney damage, increased incidence of certain types of cancer, etc.), and the World Health Organization recommends the daily salt intake should not exceed 5 grams (WHO, 2012), while the European recommendations are set at $6 \mathrm{~g} /$ day (EC, 2011).

According to results of this study, cheese in child's diet could ensure fulfilment of $47.22-67.46 \%$ of requirements for calcium, $54.22-90.37 \%$ DRI for zinc, $62.88-84.92 \%$ DRI for chromium and $47.25-70.88 \%$ DRI for selenium. Due to the lower content of 
minerals, fulfilment of recommendations from kajmak consumption is less than from cheese, with significantly lower values for the fulfilment of the requirement for iron among females older than 18 years in comparison with males $(P<0.05)$. The presence of protein, calcium and vitamin $\mathrm{D}$ in dairy products make them important in the normal growth and development of children, and supplementing the usual diet with dairy products significantly increases bone mineral density during childhood and adolescence (de Lamas et al., 2019). In addition to numerous positive health effects of milk and dairy consumption in childhood, several plausible mechanisms underlying the effect of dairy products on childhood adiposity have been discussed over the last decade. However, a recent review confirmed there is little evidence to support this concern (Dougkas et al., 2019).

For the adult population, $100 \mathrm{~g}$ of cheese should fulfil just under half the daily need for calcium for both genders, with exception of females older than 51 years and very young pregnant and lactating females which have higher calcium requirements (i.e., $1300 \mathrm{mg}$ vs $1000 \mathrm{mg}$ ) and consequently the share of fulfilment of daily needs is lower (about 40\%). Evidence has confirmed that the consumption of three or more dairy servings per day has beneficial effects on bone in adults, but even four servings per day may be necessary to achieve the nutrient status associated with optimal bone health in adulthood (US Department of Health and Human Services, 2020). Consuming 100 grams of cheese could ensure $26.69-46.71 \%$ DRI for chromium, while lactating women have a significantly higher needs for this mineral and therefore fulfil a smaller portion of the recommendations (20.85-22.59\%). Pregnant and lactating women also have higher requirements for selenium, and fulfil only $20.25-23.63 \%$ DRI, which is less than for the adult population (25.77$35.44 \%$ DRI). Regarding fulfilment of the need for iron, pregnant and lactating women are also in danger since their requirements are significantly higher $(27 \mathrm{mg} /$ day) compared to non-pregnant women $(18 \mathrm{mg} /$ day $)$ or males $(8 \mathrm{mg} /$ day). For this population, fulfilment of the requirements is only in the range of $1.13-3.82 \%$ DRI, with significantly lower values for females older than 18 years in comparison with males $(P<0.05)$. During pregnancy and lactation, the diet should provide sufficient energy and nutrients not just to ensure adequate growth and development of the foetus but also to meet mother's dietary requirements and provide good nutritional status of the mother in postpartum period and later in life. A recent review has confirmed a trend that maternal milk and dairy intake during pregnancy is positively associated with infant birth weight and length (Achón et al., 2019).

Average daily consumption of cheese and kajmak in the representative sample of the Serbian adult population were 27 and 21 grams per day, respectively (Statistical Office of the Republic of Serbia, 2020). With this amount of consumed cheese, adults should fulfil: $26.85-33.56 \%$ DRI for sodium; 9.81-12.75\% DRI for calcium; 7.21-12.61\% DRI for chromium, 6.659.15\% DRI for zinc and 6.96-9.57\% DRI for selenium. With an average consumption of $21 \mathrm{~g}$ of kajmak; the fulfilments of dietary recommendations were highest for sodium (12.26-15.33\% DRI) and lowest for selenium $(0.72-0.99 \%$ DRI) (data not shown).

\section{Conclusions}

The production of traditional and/ or regional dairy products is based on natural raw materials of good quality originating from domestic animal breeds. In this sense, raw milk produced in the Zlatibor region is whole milk 
and a quality raw material for the further production of dairy products. Though the recommended values for lipid quality indices were exceeded in the analysed products due to the undesirable high level of sodium, cheese and kajmak from Zlatibor region are still considered valuable sources of CLA, calcium, chromium, zinc and selenium. This could be attributed to several factors including animal breed, age and health, period of lactation, feeding and farming system, seasonal variations, geographical position and production process. Taking the daily consumption habits into account, a significant contribution to the quality of the diet of various populations with these products could be achieved. The data obtained in this study could be used as a case report for dairy research, and would provide information to dairy producers for product standardization and further improvements of their production system. Therefore, additional efforts are required to initiate the procedure of protection of designation of origin, which will give these products added value and enhance their valorisation.

\section{Acknowledgement}

This study was supported by the Ministry of Education, Science and Technological Development, Republic of Serbia, Grant No. 451-03-9/2021-14/200050 and the Innovation Fund of the Republic of Serbia.

\section{References}

1. ACHÓN, M., N. ÚBEDA, Á. GARCÍAGONZÁLEZ, T. PARTEARROYO and G. VARELA-MOREIRAS (2019): Effects of Milk and Dairy Product Consumption on Pregnancy and Lactation Outcomes: A Systematic Review. Adv. Nutr. 10 (suppl_2), S74-S87.

2. ALICHANIDIS, E. and A. POLYCHRONIADOU (2008): Characteristics of major traditional regional cheese varieties of EastMediterranean countries: A review. Dairy Sci. Tech. 88, 495-510.

3. AOAC (1984): Official methods of Analysis of the Association of official Analytical chemists, $14^{\text {th }}$ Edition, 24.010, p. 432, published by the Association
Official Analytical Chemists, Inc., Arlington, Virginia, USA.

4. BARAĆ, M., M. KRESOJEVIĆ, B. ŠPIROVIĆTRIFUNOVIĆ, M. PEŠIĆ, T. VUČIĆ, A. KOSTIĆ and S. DESPOTOVIĆ (2018): Fatty acid profiles and mineral content of Serbian traditional white brined cheeses. Mljekarstvo 68, 37-45.

5. BERGAMASCHI, M., C. CIPOLAT-GOTET, G. STOCCO, C. VALORZ, I. BAZZOLI, E. STURARO,M.RAMANZIN and G.BITTANTE (2016): Cheesemaking in highland pastures: Milk technological properties, cream, cheese and ricotta yields, milk nutrients recovery, and products composition. J. Dairy Sci. 99, 9631-9646.

6. DE LAMAS, M. J., M. DE CASTRO, Á. GILCAMPOS, M. L. GIL, COUCE and R. LEIS (2019): Effects of Dairy Product Consumption on Height and Bone Mineral Content in Children: A Systematic Review of Controlled Trials. Adv. Nutr. 10, S588-S596.

7. DOUGKAS, A., S. BARR, S. REDDY and C. D. SUMMERBELL (2019): A critical review of the role of milk and other dairy products in the development of obesity in children and adolescents. Nutr. Res. Rev. 32, 106-127.

8. EC (2011): Regulation No 1169/2011 of the European Parliament and of the Council on the provision of food information to consumers, Off. J. EU. L304.

9. EUROPEAN FOOD SAFETY AUTHORITY (EFSA) (2010): Scientific Opinion on Dietary Reference Values for fats, including saturated fatty acids, polyunsaturated fatty acids, monounsaturated fatty acids, trans fatty acids, and cholesterol. EFSA J. 8, 1461.

10. FAO (2013): Milk and Dairy Products in Human Nutrition. E. Muehlhoff, A. Bennett, and D. McMahon ed. FAO, Rome, Italy.

11. FAOSTAT (2012): FAO statistical database. Available at: http://faostat.fao.org/.Accessed 12 September 2012.

12. FERLAY, A. and Y. CHILLIARD (2020): Effect of linseed, sunflower, or fish oil added to hay-or corn silage-based diets on milk fat yield and trans-C18:1 and conjugated linoleic fatty acid content in bovine milk fat. Livest. Sci. 235, 104005.

13. FIL-IDF (1981): Determination of Fat Content. Gerber Butyrometers. Milk. International Dairy Federation, Brussels, Belgium.

14. FIL-IDF (1987): Determination of Total Solids Content. Milk, Cream and Evaporated Milk. International Dairy Federation, Brussels, Belgium.

15. FIL-IDF (2002): Milk, Determination of nitrogen content (Kjeldahl method) and calculation of crude protein content, IDF Standard 20 - I, Brussels, International Dairy Federation.

16. FILIP, S., R. FINK, J. HRIBAR and R. VIDRIH (2010): Trans Fatty Acids in Food and Their Influence on Human Health. Food Technol. Biotech. 48, 135-142.

17. GAUCHERON, F. (2011): Milk and Dairy Products: A Unique Micronutrient Combination. J. Am. Coll. Nutr. 30, SUP5, 400S-409S. 
18. GOVARI,M.,S.ILIADIS,D.PAPAGEORGIOU and D. FLETOURIS (2020): Seasonal changes in fatty acid and conjugated linoleic acid contents of ovine milk and kefalotyri cheese during ripening. Int. Dairy J. 109, 104775.

19. GRUMMER, J., M. KARALUS, K. ZHANG, Z. VICKERS and T. C. SCHOENFUSS (2012): Manufacture of reduced-sodium Cheddar-style cheese with mineral salt replacers. J. Dairy Sci. 95, 2830-2839.

20. HURTAUD, C., M. DUTREUIL, M. COPPA, C. AGABRIEL and B. MARTIN (2014): Characterization of milk from feeding systems based on herbage or corn silage with or without flaxseed and authentication through fatty acid profile. Dairy Sci. Technol. 94, 103-123.

21. HUTH, P. J. and K. M. PARK (2012): Influence of Dairy Product and Milk Fat Consumption on Cardiovascular Disease Risk: A Review of the Evidence. Adv. Nutri. 3, 266-285.

22. INSTITUTE OF MEDICINE (2011): Recommended Dietary Allowances: Calcium, Chromium, Copper, Fluoride, Iodine, Iron, Magnesium, Manganese, Molybdenum, Phosphorus, Selenium, Zinc, Potassium, Sodium, Chloride. Washington DC: National Academy Press.

23. INSTITUTE OF PUBLIC HEALTH OF SERBIA (IPHS) "Dr Milan Jovanovic Batut" (2020): Incidence and mortality of acute coronary syndrome in Serbia 2019. Report No 14. Belgrade.

24. ISO 5509:2000 Animal and vegetable fats and oils Preparation of methyl esters of fatty acids

25. KHAN, I. T., M. NADEEM, M. IMRAN, R. ULLAH, M. AJMAL and M. H. JASPAL (2019): Antioxidant properties of Milk and dairy products: A comprehensive review of the current knowledge. Lipids Health Dis. 18, 41.

26. KHATTAB, A. R., H. A. GUIRGUIS, S. M. TAWFIK and M. A. FARAG (2019): Cheese ripening: A review on modern technologies towards flavor enhancement, process acceleration and improved quality assessment. Trends Food Sci. Technol. 88, 343-360.

27. KUČEVIĆ, D., S. TRIVUNOVIĆ, V. BOGDANOVIĆ, K. ČOBANOVIĆ, D. JANKOVIĆ and D. STANOJEVIĆ (2016): Composition of raw milk from conventional and organic dairy farming. Biotechnol. Anim. 32, 133-143.

28. LECERF, J. M. (2009): Fatty acids and cardiovascular disease. Nutr. Rev. 67, 273-283.

29. LEŠIĆ, T., J. PLEADIN, G. KREŠIĆ, N VAHČIĆ, K. MARKOV, M. VRDOLJAK and J. FRECE (2016): Chemical and fatty acid composition of cow and sheep milk cheeses in a lamb skin sack. J. Food Compos. Anal. 46, 70-77.

30. MARASCHIELlO, C., I. DÍAZ and J. A. G. REGUEIRO (1996): Determination of cholesterol in fat and muscle of pig by HPLC and capillary gas chromatography with solvent venting injection. J. High Res. Chrom. 19, 165-168.

31. MILORADOVIC, Z., J. MIOCINOVIC, N. KLJAJEVIC, I. TOMASEVIC and P. PUDJA
(2018): The influence of milk heat treatment on composition, texture, colour and sensory characteristics of cows' and goats' Quark-type cheeses. Small Rumin. Res. 169, 154-159.

32. PARK, Y. W., M. JUÁREZ, M. RAMOS and G. F. W. HAENLEIN (2007): Physico-chemical characteristics of goat and sheep milk. Small Ruminant Res. 68, 88-113.

33. PASZCZYK, B., E. TOŃSKA and J. ŁUCZYŃSKA (2019): Health-promoting value of cow, sheep and goat milk and yogurts. Mljekarstvo 69, 182-192.

34. PIETRZAK-FIEĆKO, R. and A. M. KAMELSKA-SADOWSKA (2020): The comparison of nutritional value of human milk with other mammals' milk. Nutrients 12, 1404.

35. PRECHT, D. (1992): Detection of Foreign Fat in Milk Fat. I. Qualitative Detection by Triacylglycerol Formulae. Int. J. Food Res. Tech. 194, 1-8.

36. PUDJA, P., J. DJEROVSKI and $M$. RADOVANOVIĆ (2008): An autochthonous Serbian product - Kajmak Characteristics and production procedures. Dairy Sci. Tech. 88, 163-172.

37. RAYNAL-LJUTOVAC, K., G. LAGRIFFOUL, P.PACCARD, I.GUILLET and Y.CHILLIARD (2008): Composition of goat and sheep milk products: An update. Small Rumin. Res. 79, 57-72.

38. RICE, B. H., E. E. QUANN and G. D. MILLER (2013): Meeting and exceeding dairy recommendations: Effects of dairy consumption on nutrient intakes and risk of chronic disease. Nutr. Rev. 71, 209-223.

39. RULEBOOK ON SAMPLING METHODS AND METHODS OF CHEMICAL AND PHYSICAL ANALYSIS OF MILK AND MILK PRODUCTS (1983): Official Gazette of SFRY, No. 32/83.

40. STATISTICAL OFFICE OF THE REPUBLIC OF SERBIA (2020): Household Budget Survey 2019, Bulletin 662, Belgrade.

41. TRBOVIC, D., D. SPIRIC, M. LUKIC, Z. PETROVIC, N. PARUNOVIC, V. DJORDJEVIC and D. MILICEVIC (2017): Fatty acid composition of cow's milk: Opportunities and challenges for Serbian dairy producers. Meat Technol. 58, 118-124.

42. ULBRICHT, T. L. V. and D.A.T.SOUTHGATE (1991): Coronary heart disease: Seven dietary factors. The Lancet 338, 985-992.

43. US DEPARTMENT OF HEALTH AND HUMAN SERVICES (2020): Dietary Guidelines for Americans, $9^{\text {th }}$ ed., Washington, DC.

44. VAHČIĆ, N., M. HRUŠKAR, K. MARKOVIĆ, M. BANOVIĆ and I. COLIĆ BARIĆ (2010): Essential minerals in milk and their daily intake through milk consumption Mljekarstvo 60, 77-85.

45. VUČIĆ, V., A. ARSIĆ, S. PETROVIĆ, S. MILANOVIĆ, M. GURINOVIĆ and M. GLIBETIĆ (2015): Trans fatty acid content in Serbian margarines: Urgent need for legislative changes and consumer information. Food Chem. $185,437-440$. 
46. VULiĆ, A., N. KUDUMIJA, T. LEŠIĆ, S. TANKOVIĆ, V. JELUŠIĆ, J. FERIZBEGOVIĆ, N. BILANDŽIĆ and J. PLEADIN (2021): Chemical composition and fatty acid profile of alpine and saanen goat milk from Bosnia and Herzegovina. Vet. stn. 52, 13-21.

47. WHO (2012): Guideline: Sodium intake for adults and children. World Health Organization, Geneva, Switzerland.
48. WOODS, V. B. and A. M. FEARON (2009): Dietary sources of unsaturated fatty acids for animals and their transfer into meat, milk and eggs: A review. Livest. Sci. 20.

49. YAO, Y., G. ZHAO, J. XIANG, X. ZOU, Q. JIN and X. WANG (2016): Lipid composition and structural characteristics of bovine, caprine and human milk fat globules. Int. Dairy J. 56, 64-73.

\section{Karakterizacija i nutritivna ocjena tradicionalnih mliječnih proizvoda s područja Zlatibora u Republici Srbiji}

Dr. sc. Dragan MILIĆEVIĆ, znanstveni savjetnik; dr. sc., Danijela VRANIĆ, viša znanstvena suradnica, dr. sc., Saša JANKOVIĆ, viši znanstveni suradnik, Institut za higijenu i tehnologiju mesa, Beograd, Srbija; dr. sc. Greta KREŠIĆ, redovita profesorica, Fakultet za ugostiteljstvo i turizam Sveučilišta u Rijeci, Opatija, Hrvatska; Tina LEŠIĆ, mag. ing., viša stručna suradnica, doktorandica, dr. sc. Jelka PLEADIN, znanstvena savjetnica u trajnom zvanju, redovita profesorica, Hrvatski veterinarski institut, Zagreb, Hrvatska; dr. sc. Jelena NEDELJKOVIĆTRAILOVIĆ, redovita profesorica, Veterinarski fakultet, Univerzitet u Beogradu, Beograd, Srbija

Cilj ovog istraživanja bio je ustvrditi nutritivna svojstva sirovog mlijeka, sira i kajmaka proizvedenih po tradicionalnim recepturama podrijetlom s područja Zlatibora u Republici Srbiji. U tu su svrhu nakon tri uzorkovanja u razdoblju od lipnja do rujna 2019. ispitivani: kemijski sastav, minerali, profil masnih kiselina (MK), indeksi kvalitete lipida, prehrambeni unos zasićenih masnih kiselina (ZMK), kolesterola, soli i natrija. Sirovo mlijeko, sir i kajmak su se značajno razlikovali $(P<0,05)$ po svim kemijskim svojstvima, osim u udjelu laktoze, soli i ukupnih bjelančevina. $U$ istraživanju profila masnih kiselina, najveći udio ustvrđen je za palmitinsku (C16:0), oleinsku (C18:1 cis-9) i miristinsku (C14:0) kiselinu, bez značajnih razlika $(P>0,05)$ među proizvodima. Među MK ustvrđena je konjugirana linolna kiselina (KLK), sa srednjim vrijednostima ukupnih MK u rasponu od 0,16\% u sirovom mlijeku i kajmaku do 0,31 \% u siru. U analiziranim proizvodima za indekse kvalitete lipida nisu određene preporučene vrijednosti. Unatoč visokom udjelu natrija, analizirani mliječni proizvodi mogu se smatrati dragocjenim izvorima kalcija, kroma, cinka i selena. Potreban je nastavak budućih istraživanja modifikacije ovih proizvoda s ciljem optimizacije njihove hranjive vrijednosti i zaštite oznakom izvornosti.

Ključne riječi: sirovo mlijeko, sir i kajmak, hranjiva vrijednost, tradicionalna receptura, područje Zlatibora 